$\mathrm{A} 1$ の純度は $\mathrm{Al}-\mathrm{Hg}-\mathrm{Zn}$ 系の場合影響が顕著で 99.9 \%から 99.7\%に下がると効率は $25 \%$ も下がる。しか

し電位に及ぼす影響は少なかった。

目下大規模の現場実験が進められており，その結果も 研究室の結果を裏付けているので, 海中では $\mathrm{Al}-\mathrm{Hg}-\mathrm{Zn}$ 合金はきわめて有望であろうと思う。

結論

以上を総合してみると, $\mathrm{Al}$ に $\mathrm{Hg}, \mathrm{Ga}, \mathrm{Sn}, \mathrm{In}, \mathrm{Bi}$, $\mathrm{Mg}, \mathrm{Zn}, \mathrm{Cd}, \mathrm{Bi}$ などを加えた合金は $\mathrm{A} 1$ 単体よりも卑 な電位を示す。またこれらの諸元素のある種のものを組 合せた二元添加合金はさらにすぐれた性能定示す。
特に $\mathrm{Al}-\mathrm{Hg}-\mathrm{Zn}$ 系は海水中で $-1.05 \mathrm{~V}$ の電位と $1,290 \mathrm{~A}-\mathrm{hr} / \mathrm{lb}$ の発生電気量を示しきわめて有望なよう に思わ的。

\section{引用文 献}

H. A. Robinson: Trans. Electrochem. Soc, 90, 489 490 (1946)

R. A. Hine \& M.W.Wei: Mater. Prot., 3, 50 (1964) Nov.

\section{他の関連記事}

T. Sakano, K. Toda \& M. Hanada: Test on the Effects of Indium for High Performance Aluminum Anodes. Mater. Prot., 5, No. 12, 45 (1966) Dec.

C. H.Mackdanz: Protection of Offshore Structures. Mater. Prot., 4, 83 (1965) Oct.

J.R. Wellington: The Low Potential Zinc Anode in Theory and Application. Corrosion, 17, 550 t(1961) Nov.

\title{
循環式冷却水装置の硫酸塩還 元バクテリア*
}

Edward Tehle**

開放型循環冷却水装置にはバクテリアが集積すること がしばしばある。硫酸塭還元バクテリアの存在を示す文 献も若干あるが，空気写含も状態でもなお存在しうるこ とを示したものは少ない1,2)。

硫酸塩還元バクテリアは新陳代謝の際 $\mathrm{H}_{2} \mathrm{~S}$ を造る。 これが (1) 腐食を促進する。(2) クロム酸塩を還元す る。(3) 不溶性の硫化物を造り污損問題を招く。

それゆえ，2力年にわたり米国各地から循環式冷却水 塔の水試料を集めて硫酸塩還元バクテリアの調査を進め た。水は殺菌剂を使用していない塔のものを主とした。

また，クロム酸塩は硫酸塩還元バクテリアに有効な抑 制剂とされているのでクロム酸塭を含む冷却水の還元バ クテリアには特に注意を払っだ3。

\section{実 験方 法}

冷却水とスラッジの試料は無菌の 4 オンス容器に入れ て研究室に集め分析した。試料は塔の下の池の水を流れ と攪乱の強い場所で採取し，可能なかぎり池の中のスラ ッジ試料も集めて分析に供した。

硫酸塩還元ハシクテリア存在の確認には A. P. I.4) の決 めた培養基と方法を用いた。この方法の大要は，(1) す ベての栄養価值のある配合を溶かし込む。（2）培養基の $\mathrm{pH}$ は $\mathrm{NaOH}$ を用いて 7.5 に調節する。(3)この液を ネジ蓋つきの培養管に注入する (各管 $9 \mathrm{~m} l$ )。(4) 充继 した管をオートクレーブに入れて 10 分間 15 psi の蒸気 で蒸す。(5) 管を取り出し $45^{\circ} \mathrm{C}$ に浴湯で泠やして後, 試料の水やスラッジを加える。

* 訳者：花田政明（日本防蝕工業株式会社）

** Dearborn Chemical Div., W. R. Grace \& Co., Chicago, III.

(原文) Sulfate Reducing Bacteria in Water Cooling Systems. Mater. Prot., Vol. 5, No. 12, 21 22 (1966) Dec.

\section{バクテリアは生存しうる}

分析の結果は開放型循環使用の冷却水でも硫酸塩還元 バクテリアが生存しうることを示した。還元バクテリア 注調查した冷却水の $32 \%$ で存在定し, その数は最少 10 カウント $/ \mathrm{m} l$ 最大 16,000 カウント $/ \mathrm{ml}$ であった。 もちろんスラッジにも存在しうるのである。

分析が示したクロム酸塭の量汇範囲㤎広く $0 \sim 235$ $\mathrm{ppm}$ に及ぶ。本調査に関するかぎり $48 \mathrm{ppm}$ 以上のク ロム酸塩濃度 $\left(\mathrm{CrO}_{4}\right.$ として）では還元バクテリアは存 在しない。50 ppm くらいのクロム酸塩濃度に達すると 殺菌効果があるように考えられる。しかしさらに詳しく 致死量や抑制効果の限界值, 他の金属イオンの影響など を調べる必要がある。

硫酸塩還元バクテリアが検出された水には $\mathrm{SO}_{4}$ とし て 47〜4,900 ppm の硫酸塭があった。その $\mathrm{pH}$ 值は $6.2 \sim 9.3$ 範囲であったが大部分は $6.7 \sim 7.2$ の範囲にあ った。

冷却水からは硫酸塩還元バクテリアが検出されなかっ た装置から採ったスラッジ試料の $35 \%$ から硫酸塩還元 バクテリアが検出された。またバクテリアの量も多く 900 カウント $/ \mathrm{m} l \sim 200,000$ カウント $/ \mathrm{m} l$ であった。

\section{バクテリアの防止}

硫酸塩還元バクテリアは嫌気性であるから, 池の中の スラッジや沈殿物は嫌気性バクテリアに恰好の環境を与 えることになる。殺菌法は殺菌剤と殺菌細胞との直接接 触を眓ればよいので比較的簡単である。

ただ不幸なことに，水の中ではすぐれた防止法でも最 もバクテリアの生育しやすい場所にはとどかない。沈殿 物やスラッジからなる污染物の塊がバクテリアと殺菌剂 の接触を妨げるからである。 
有効な防止策としては沈殿物やスラッジ内のバクテリ アと殺菌剤を十分接触させることを特に重視する要があ

る。その手段として考えられることには：

沈殿物やスラッジの生因を除くことは当然有効であ る。バクテリアの生長しうる環境を除くことを意味し， 防污剤它加えて清浄に保つことは有効である。

殺菌刜を沈殿物中に注入することは菌と殺菌剤の直接 接触を図ることになり有効である。

スラッジの塊を貫通できる殺菌剤を使用することも有 効であり，これには表面活性のある殺菌凨がある。

現在使用されている殺菌凨には次のようなものがあ る。

\section{1) 塩 素}

塩素は広く使われる殺菌剤である。これが有効なため には十分な残存量があることが必要である。塩素は酸化 剤であるからすべての有機物と反応するので有機物の沈 殿物やスラッジの中で十分な残存量を維持することはな かなか困難である。

硫酸塩還元バクテリアは塩素に耐える能力があるとい う報告があるが，おそらくバクテリアの存在する環境で 他の硫化物と反応するため殺菌に必要な残存量の維持が 困難なためであろう5)。

2) 多塩化フェノール

塩化フェノールの塩は用途の広いすぐれた殺菌剤であ る。循環冷却水中の硫酸塩バクテリアをおさえるにも有 効であるが， スラッジや沈殿物を貫通する能力がないか ら，沈殿物中に吹き込むかあるいは沈殿物やスラッジを 攪汼しながら注入しないと沈殿物の下のバクテリアを殺 すのに適しない。

3）四基化合物

多くのアルキルアリルおよびアルキル複素環式四基化 合物は，硫酸塩還元バクテリアに有効である。これらは 表面活性があるので沈殿物やスラッジを突き抜けて働 $<。$

この種の薬剤の欠点は

（1）泡になりやすいとと，(2) その所要量が相当大き いこと，(3) 硬水で活性を失なう可能性があることで ある。

4) 脂肪族アミン類
脂肪族のアミンやジアミンも硫酸塭還元バクテリアを おさえる力がある。 $\mathrm{C}_{12} \sim \mathrm{C}_{16}$ の鎖の長いものが最も有効 なようである。

多少水に溶けにくい欠点があるが，四基化合物と組合 せれば解決される。この両者を混ぜたものはきわめて有 効な総合作用定す。

5）有機硫黄化合物

この種の化合物は開放型循環冷却水にはあまり使わな い。きわめて有効な殺菌剤となるものが多いが，次の問 題があるので用途が限定されるのである。

(1) 適合性の問題, (2) 溶解度の不足, (3) 腐食性。 結

論

硫酸塩還元バクテリアは, 開放型循環式冷却水装置の $32 \%$ から検出された。 $\mathrm{CrO}_{4}$ が $50 \mathrm{ppm}$ に達すると存 在し得ないらしい。

硫酸塩還元バクテリアが存在するおそれのあるときは スラッジや沈殿物を調ベる必要がある。嫌気性であるた めに水中よりもスラッジや沈殿物中に存在しやすいから である。水に検出されないからといって安心はできな W。

硫酸塩還元バクテリアの殺菌剤はいろいろある。冷却 水中の殺菌はやさしいが, 沈殿物やスラッジ内のバクテ リアの効果的な殺菌あるいは生育抑制が必要である。こ のためには殺菌剤注入と同時にスラッジや沈殿物を攪拌 したり直接スラッジ内に注入して囷と殺菌剤定直接接触 させることが有効である。

\section{引用文献}

1) C.E.Zobell: Ecology of Sulfate-Reducing Bacteria. Producers Monthly, 22, 7 (1958) May

2) O.B.Williams: A Comparison of the Susceptibility of Various Strains of Sulfate-Reducimg Bacteria to the Action of Bactericides. Producers Monthly, 22, 10 (1958) Aug.

3) J. P. M. Drumond \& I. R. Postgate: A Note on the Enumeration of Sulfate-Reducing Bacteria in Polluted Water and on Their Inhibition by Chromate $J$. Aptied Bacteriology, 18, 307 311 (1955)

4) Recommended Practice for Biological Analysis of Water-Flood Injection Waters. API RP 38, American Petroleum Institute, Dallas, Texas

5) J. M. Sharpley: Applied Petroleum Microbiology, Buckman Laboratories, Inc., Memphis, Tenn., pp. 141 (1961) 